Comparative Philosophy Volume 12, No. 1 (2021): 157-169

Open Access / ISSN 2151-6014 / www.comparativephilosophy.org

https://doi.org/10.31979/2151-6014(2021).120113

CONSTRUCTIVE-ENGAGEMENT DIALOGUE

PHILOSOPHY OF MIND

AUTHOR MEETS CRITICS:

\title{
BUDDHIST MODERNISM, SCIENTIFIC EXPLANATION, AND THE SELF
}

\author{
SEAN M. SMITH
}

\begin{abstract}
Allow me to begin by expressing my gratitude to Karsten Struhl and the editors of Comparative Philosophy for the opportunity to engage with these ideas. This work is very close to my heart and I am always keen for the opportunity to work through the details in partnership with like-minded scholars. Struhl's (2020) paper gave me a lot to think about, and so for my reply I will divide my remarks into three sets of questions. To begin, I explore Struhl's approach to Buddhist philosophy and the role that Buddhist modernism is playing as a frame for his hermeneutical choices. I suggest here that spreading his attention to other sources of Buddhist philosophy beyond the Pāli suttas would help strengthen his argument and the connective tissue between Buddhist and contemporary approaches to the negation of self. In the second section, I look at the relevant differences between Buddhist and modern scientific approaches to the negation of self and suggest that these approaches have less in common than Struhl suggests. Finally, I turn to the Buddhist soteriological project that motivates their approach to self-negation and to Struhl's reflections on the problem of suffering and its solution through vipassanā meditation. Here I present an alternative way of understanding the problem and its solution in a Buddhist philosophical register.
\end{abstract}

\section{BUDDHIST MODERNISM AND HERMENEUTICS}

Struhl begins his paper with a common trope that early Buddhism - indeed, for many, the Buddha himself - never denied the existence of the self: "It is important to say at the outset that Buddhism is not denying that there exists a self in any sense of the term" (Struhl 2020, 114). He then goes on to quote Olendzki $(2016,41)$ and Batchelor $(2011$,

SMITH, SEAN M.: Assistant Professor of Philosophy, University of Hawaii at Mānoa, USA. Email: sean.smith@hawaii.edu 
133) who both say something similar. They also both attribute the view (or lack thereof) to 'The Buddha' and 'Gotama'. This kind of framing is very modernist and susceptible to a number of philological and conceptual critiques that Stuhl need not take on for himself.

For starters, the remainder of his paper is relentlessly anti-realist about the self, so it's not clear what purpose is served by claiming the Buddha wasn't a full-blow metaphysical anti-realist about the self. ${ }^{1}$ Second, it's philologically suspect to claim that the Pāli suttas give us any clear understanding of what the historical Buddha actually thought. Of course there are those who disagree; the author's Struhl cites are good examples. But they are also committed Buddhists and their work attempts to do problematic historical end-runs around the Buddhist traditions that arise in response to the Pāli canon and its Chinese āgama parallels. ${ }^{2}$ Third, this claim is almost certainly false. While it is true that the Buddha is never portrayed in the suttas as coming flat out and saying 'there is no self', he does say that 'all dhamma-s are not-self' (sabbe dhammā anattā) in a number of places (e.g. Dhp XX, 279). ${ }^{3}$ Further, this claim about dhamma-s directly entails the non-existence of the self. Additionally, the entire Indian Buddhist tradition, including the Pāli Abhidhamma and commentarial texts, are relentless in their metaphysical anti-realism about the self. Thus, portraying the suttas as agnostic about the existence of the self introduces a substantial schism into Buddhist philosophical hermeneutics, one that is either tacitly or explicitly committed to the claim that the entire Indian tradition of Buddhist philosophy got the suttas wrong (Smith, forthcoming). I'm not sure if this is the kind of commitment Struhl wants to build into his argument. ${ }^{4}$

Struhl then goes on to parse the argument from control in the Anattalakkhana Sutta (SN III 66) claiming that: "For the self to be an agent, for it to be an executive control center, it must be capable of controlling each of the aggregates. But again none of the aggregates either separately or collectively is subject to control. We cannot control the processes that arise in either the mind or the body. Thus, here again, none of the aggregates either separately or collectively can be a self" (Struhl 2020,116). There is a subtle discrepancy here between how Struhl understands the argument and what the text actually reports. Here's the relevant passage:

Form, bhikkhus is not self...Feeling is not self...apperception is not self... formations are not self...Consciousness is not self. For if, bhikkhus, consciousness were self, this consciousness would not lead to affliction, and it would be possible in consciousness: 'Let my consciousness be thus; let my consciousness not be thus.' But because consciousness

\footnotetext{
${ }^{1}$ By 'metaphysical anti-realism about the self' I mean the view that there is no such thing as a self.

${ }^{2}$ Another example is Gombrich (2009).

${ }^{3}$ See Hamilton $(2000,19)$ and fn. 3 on p. 31 for the following references: AN I, 286; Dhp 5-7 and 27779; MN I, 336; DN II, 157.

${ }^{4}$ It is also important to understand the place of anattā theory in Buddhist philosophy. Struhl claims that "For Buddhism, the proximate cause of this suffering is craving and attachment, but this is, in turn, generated by the belief in the self as defined above" $(2020,115)$. But the generation of craving is caused by vedan $\bar{a}$ not the belief in self. In the 10 and 12 point schemes of dependent origination the condition (paccaya) for the arising of craving is vedana
} 
is not self, consciousness leads to affliction, it is not possible in consciousness: 'Let my consciousness be thus; let my consciousness not be thus.' ${ }^{5,6}$

For Struhl, the self is understood as something separate from the aggregates and its status as a self is measured by the extent to which it is capable of controlling them. By contrast, in the text, it is the aggregates themselves that are being canvassed as possible candidates for being the self. The criterion for selfhood is not an aggregate-independent controller of one or all of the aggregates. Instead, each aggregate is considered and rejected as being the self because they are not subject to the exercise of control. That is, the aggregates are not the self because they can't be controlled. ${ }^{7}$

Struhl then points out that this argument, as well as the argument from impermanence, do not yet get us all the way to metaphysical anti-realism about the self: "However, these arguments alone could not establish that there is no self, since the self could in principle be something beyond the aggregates, something which is permanent and which controls the aggregates but which is not itself one of the aggregates, something that is a possessor and observer of the aggregates but not itself the aggregates" (Struhl 2020, 116). This is a common claim made by those Pāli apologists who wish to construe the Buddha of the suttas as a metaphysical agnostic (see Davis 2016 in addition to the references above). However, the relevant reply to such reasoning is in the following passage: "Bhikkhus, indeed whatever recluses or brahmins, (who), regard the self in different ways, in so regarding, they all regard the five aggregates subject to clinging or a certain one of these" (SN III, 46; see also Bodhi 2017, 33). ${ }^{8}$ This passage is attempting an exhaustiveness claim; any recluse who has any view of the self will actually be mistaking the self for one or more of the aggregates. Therefore, this exhaustiveness claim coupled with the conclusions of the arguments from control and impermanence entail that there are no selves. ${ }^{9}$ As far as I can tell, this result is good news for Struhl because it makes the lines of argument he considers from the suttas more resonant with his contemporary sources. But as I shall point out below, even with a more consistently anti-realist construal of the suttas in hand, there remain important methodological and metaphysical differences between Buddhist anti-realism about the self and modern scientific anti-realism about the self.

\footnotetext{
${ }^{5}$ All translations are my own unless otherwise indicated. I use suttacentral.net and the online Digital Pāli reader for the root text. I cite the PTS editions as is the scholarly standard. I include English editions of the relevant texts in the bibliography.

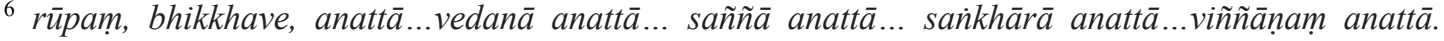
viñ̃̄ānañ̄ca hidam, bhikkhave, attā abhavissa, nayidam viññānam ābādhāya saṃvatteyya, labbhetha ca viññāne: 'evam me viññānam hotu, evam me viññānam mā ahosī'ti. yasmā ca kho, bhikkhave, viñ̃āṇam

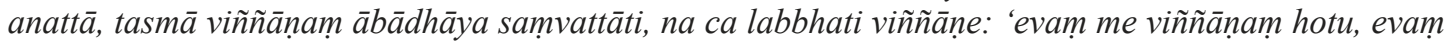
me viñ̃̃ānam mā ahosì'ti.

${ }^{7}$ For more on this argument, see Wynne (2009).

${ }^{8}$ Ye hi keci, bhikkhave, samañā vā brāhmanā vā anekavihitam attānam samanupassamānā samanupass anti, sabbe te pañcupādānakkhandhe samanupassanti, etesam vā añ̃ataram.

${ }^{9}$ See Smith (forthcoming) for an extended treatment of this issue.
} 


\section{BUDDHIST VS. SCIENTIFIC NEGATION OF SELF}

I now wish to treat of Struhl's interpretation of neuroscience and biology. First, I point out some relevant differences between contemporary scientific approaches to selfnegation - what Evan Thompson $(2015,322)$ calls 'neuro-nihilism' - and Buddhist approaches to self-negation. While Struhl seems to think the connections are clear and transparent, I'm not so sure. Second, I want to briefly explore Struhl's considerations of biology and Buddhist self-negation. Here I will suggest that there are multiple ways to construe this connection and that Struhl's favored way may not be the most apt.

\subsection{NEUROPHILOSOPHY AND ANTI-REAALISM ABOUT THE SELF}

Struhl's main ally here is philosopher Thomas Metzinger $(2003 ; 2009 ; 2011)$. Struhl sees Metzinger's anti-realism about the self as helpful for analyzing the 'underlying causes' of the phenomenal self (Struhl 2020,124). One relevant point here is that Metzinger is an identity theorist about physical and mental events, he thinks that phenomenal states are identical with brain states (Metzinger 2003). The language of cause and effect implies a difference of identity between causal relata. So, if a brain state is the cause of a phenomenal state, then the two cannot be identical. Thus, for Metzinger, brain states don't cause mental states, they are mental states. This fact bears on the way in which Metzinger's brand of anti-realism about the self differs from Buddhist approaches. Metzinger's underlying metaphysical commitments to physicalism and neural-representationalism motivate his anti-realism about selves. These commitments are not at the forefront of Strulh's consideration of Metzinger's contribution, but I wonder if centering them more might affect our understanding of the relevance of Metzinger's scientific approach to anti-realism about the self in comparison with Buddhist approaches.

For Metzinger, our sense of self and our sense of being intentionally related to a phenomenally experienced world are the results of neural simulations - for the self, it's a Phenomenal Self Model (PSM) and for the intentionality relation it's a Phenomenal Model of the Intentionality Relation (PMIR) (Metziner 2003). What makes the self an illusion is that it is merely a neural simulation. All there really is, is the coordinated biochemical pulsations of the neural system in response to stimuli from the environment. The phenomenal self and its experiential world are simply neutrally generated user-illusions. What is actually real is the physical events in the brain that physically realize these user illusions.

My question at this juncture is: how does this brain-bounded simulational representationalism square with Buddhist views that see the mind and body as dynamically related phenomena? For Buddhist philosophers, even those who disagree strongly with each other about metaphysics - like Abhidharmikas and Madhyamikas, for example - mental categories corresponding to what we would call 'consciousness' are explanatorily basic in various conceptual schemes that are used to analytically decompose the self. For example, in Abhidharmic analysis, Pāli terms like vinnāna and vedan $\bar{a}$ constitute irreducible members of the explanatory base to which the self (atta) 
is reduced. ${ }^{10}$ Therefore, for the Buddhist philosopher, what is being reduced or eliminated (the self) is reduced to a reduction base which is in fact real. That reduction base includes phenomenal kinds which are explanatorily, and in some cases, metaphysically basic. By contrast, for Metzinger, the reduction base is nothing but nonphenomenal neural events. ${ }^{11}$ Thus, my question for Struhl at this juncture is how he understands the relationship between Buddhist anti-realism about the self and modern scientific anti-realism about the self? These two approaches to the self-as-illusion have very different understandings of what the self is being reduced to. For Buddhist philosophers, the reduction base contains phenomenal kinds, for Metzinger the reduction base is strictly neuro-physical. So, how could Metzinger's physicalist brand of illusionism about the self be consistent with a variety of Buddhist approaches to antirealism about the self? There is also an important difference here about how the phenomenology is construed. For Metzinger, the infrastructure of the PSM and PMIR is constitutively egocentric $(2003,2 ; 2011,291)$. The elimination of self occurs across levels of description from the phenomenally personal to the neurally impersonal, how things seem first-personally is preserved. By contrast, for Buddhist philosophers, the elimination of self occurs within the framework of experience where phenomenal kinds constitute parts of the reduction base; self is an illusion, consciousness is not. ${ }^{12}$ This means that there is something it is like to be selfless for the Buddhist. Now, we argue that the Buddhist position is inconsistent on this point, but understanding the relevant differences is important here if we want to use disparate historical and conceptual resources to argue for a systematic point about what there is or isn't in the world.

\subsection{EVOLUTIONAARY BIOLOGY AND THE USES OF THE SELF}

I now transition to a brief treatment of Struhl's attempt to marry Buddhist anti-realism about the self with evolutionary biology. Struhl uses biological categories to interpret the function of the PSM so as to pose a dilemma for the Buddhist anti-realist about the self. Here I will try to answer that dilemma on behalf of the Buddhist philosophers and offer some questions about Struhl's use of biological categories to interpret Buddhist philosophical views.

Struhl's point here, as far as I can tell, is that the PSM is powerfully useful in spite of its status as a neutrally generated user-illusion. "It is a device for directing our behaviors so that we can efficiently navigate both the physical and social world... The

\footnotetext{
${ }^{10}$ This is true of Madhyamikas as well, but with the difference that Madhyamaka thought eschews any kind of foundationalism. In what immediately follows, I use the language of 'reduction' and 'reduction base,' terms that would make a Madhyamika uncomfortable. Even so, these Buddhist philosophers embrace the philosophical psychology of Buddhist soteriology without reifying the referents of those terms. Perhaps the same cannot be said of their Abhidharmika counterparts. I cannot get any further into the philosophical specifics here; for more, see Westerhoff (2009).

${ }^{11}$ It is important to note that some contemporary Buddhist philosophers have tried to make Buddhist philosophical psychology consistent with contemporary scientific naturalism (Garfield 2015; Siderits 2013). But these views are creative re-imaginings of Buddhist ontological commitments rather than faithful reconstructions.

${ }^{12} \mathrm{Or}$, if consciousness is an illusion, so is everything else that is dependently originated.
} 
illusion of self also has an important internal function for the human organism. It evolved so that a multitude of experiences which would otherwise be fragmented could be bound together" (Struhl 2020, 127). Struhl then uses this point about utility and causal efficacy to generate a dilemma for Buddhist anti-realism about the self. He explains: "We are now left with a dilemma for Buddhism's soteriological project. Buddhism insists that the illusion of self is the ultimate cause of $d u k k h a$ and argues that enlightenment requires extinguishing this illusion. On the other hand, Buddhists need to recognize that the illusion of self is at least highly useful if not essential for the survival and continued development of the human species" (Struhl 2020, 128). I have two replies to offer on behalf of the Buddhist philosopher here. The first is: assuming the definition of the PSM Struhl is working with here, why should we consider such a device an illusion? From a Buddhist perspective, something's having causal efficacy marks it as real, so if the PSM has causal efficacy, then it's real. So, even if we buy into Metzinger and Struhl's view that there is a neural PSM, it's not clear why that entity would be an illusion. Second, Buddhists would deny that the PSM bears the causal load ascribed to it here but would instead advert to the distributed local processes that collectively organize behavior (dharma-s). These organized constituents are both psychological and physical (rather than just neural). Thus, from a Buddhist point of view, we can understand the sense we have of ourselves as a unified phenomenal self in terms of what Mark Siderits calls a 'shifting coalition' of psychological and physical processes that generate that sense (Siderits 2007, 49). As Siderits points out, "....it need not be the same part of the person that performs the executive function on every occasion" (ibid). When we recognize that different parts of the system are capable of achieving executive function in concert with other parts of the system, the problem of assuming a central PSM disappears. That is, there is no need for a one-to-one mapping from the phenomenology of self to the neural implementation of the self. Such a mapping reifies the illusion of singularity that is present at the phenomenal level of description into the neural architecture. ${ }^{13}$

It is also worth emphasizing that this debate about whether or not we need a functional definition of a self or person - at the neural level via Metzinger's PSM, or even just a notion of personhood more generally to explain the alleged utility of conceiving of ourselves as selves - is a topic of intense debate in the history of Buddhist philosophy. In particular, Vasubadhu's debate with the Pudgalavādins seems extremely important here (see Lusthaus 2009 and Duerlinger 2009 in Edelglass and Garfield 2009). The Pudgalavādins echo Struhl's point about utility by claiming that without some notion of personhood that is neither reducible to, nor wholly independent from, the psychophysical elements that compose the individual, the Buddhist philosopher is in no position to explain the diachronic continuity of person stages that individuate us as the karmically situated beings that we are. Vasubandhu replies that causal continuity among the dharma-s is more than sufficient to do this explanatory work. I mention this point by way of noting that the relevance of Buddhist philosophy to debates about self

\footnotetext{
${ }^{13}$ Though, see Christoff et al. (2011) - pace Metzinger (2003; 2011) - for a scientifically informed argument that the self is a perfectly viable construct for neuroscience.
} 
and personhood and the nature of that illusion extend far beyond the ken of the Pāli suttas and that consideration of these debates might be an avenue for enriching the discussion and making the conceptual connections between modern scientific approaches to anti-realism about the self and Buddhist approaches more consonant with one another.

Another intriguing place where Struhl's Buddhist-inspired anti-realism makes contact with biological science is in his endorsement of Wright's recent book Why Buddhism is True (2018). Both Struhl and Wright employ genocentric evolutionary biology as a hermeneutical lens for diagnosing the kinds of craving-based attitudes Buddhist philosophy is at pains to reject. For Struhl and Wright, our minds are the results of selection pressures that have shaped our cognitive habits. These habits function to extend the reproductive cycle. In Struhl's words, "The grid of natural selection does not function to develop an accurate perception of reality but to perpetuate and proliferate the gene pool" (Struhl 2020, 127). The idea here is that the pervasive force of natural selection has shaped us to be craving oriented appropriators and replicators, proliferators of genes, and by Buddhist lights, proliferators also of samsāric continuity and dukkha. By contrast, the Buddhist path of liberation helps us to see things as they are rather than just as natural selection intended us to see them. Seeing things as they are helps us escape from the problematic influence of our genetic programming.

Evan Thompson's critique of this way of thinking about the connection between Buddhist philosophy and modern science is thorough and devastating (Thompson 2020 , Ch. 2). Instead of rehearsing his many points, I will content myself with one alternative suggestion for conceptualizing this connection and encourage all interested parties to read Thompson's entire book with care. My suggestion is this: natural selection is perhaps not best thought of as something that functions on perceptual systems for a purpose because evolution doesn't have norms or values. Evolution by natural selection is the result of blind processes of organisms struggling in their environments and in so doing passing on phenotypes that help their progeny continue that struggle (see Walsh 2015). That organisms struggle this way means that living beings are not just the passive receivers of naturally selected for traits. Rather, "...organisms modify the environment in regular ways that thereby impose systematic biases on selection pressures that they themselves generate" (Thompson 2020, 65). Such a view accords much more closely with Buddhist views of the karmic construction of the world (loke) through the collective intentions (cetanā) of those sentient beings who live in and thereby shape those worlds. Thus, my suggestion here is that the connective tissue between evolutionary biology and Buddhist soteriology might be closer than Struhl thinks but that this further closeness eludes his construal of this connection because of his reliance on Wright's problematic endorsements of evolutionary psychology and genocentrism. 


\section{THE SOTERIOLOGICAAL PROBLEM AND ITS SOLUTION}

In my final set of questions, I want to engage with Struhl's interpretation of Buddhist soteriology and the practice of vipassanā meditation. I will suggest alternative ways of understanding Buddhist soteriology and meditation practice. Contrary to Struhl and Siderits's (2015) view, I claim that there is a notion of meaning and purposefulness in life available to the Buddhist that does not entail the existence of a self (Parfit 1984, 281). Additionally, I will argue that we should not think of mindfulness meditation as a way of verifying Buddhist philosophical insights but as a way of actively conditioning the perceptual apparatus such that those Buddhist principles and views we antecedently endorse become pre-reflective ways of taking up with our world, thus transforming us and our experience of that world (Shulman 2014).

The problem that Buddhists are trying to solve is the problem of dukkha, it has several dimensions, which are elaborated on in some detail by Abhidharmic commentators like Buddhaghosa (see Vis 499, XVI 34-35). One of the most pertinent aspects of our existential predicament is the inevitability of death. The end of the path of practice that helps one overcome death is nibbāna, the cessation (nirodha) of craving (tanha) and ignorance (avijja). One of the many epithets of nibbāna is the deathless (amatta). Struhl and Siderits (2015) interpret death as a problem because its inevitability prevents us from living happy lives. Following Siderits (2015), Struhl claims that (Struhl 2020, 121):

...the wish that life does not end with death is also motivated by the general goal of human happiness insofar as that goal is bound up with the attempt to give one's life meaning and purpose as a whole, a meaning and purpose which go beyond and situate our specific projects in the more encompassing project of human happiness. Belief in the self gives one the sense of being the narrator and central character of one's life and, therefore, gives one's life events a sense of a larger meaning and purpose. But this, in turn, requires that this "self" be open continuously to the future. Without such a central character, the more general goal of human happiness seems insubstantial and transient.

In a footnote to the above passage, Struhl approvingly cites Siderits $(2015,46)$ : "Realizing one's mortality radically undermines this [happiness-seeking] enterprise. The difficulty is not just that my present projects come to seem parochial and thus trivial...[but] that such projects derive their point from the larger happiness-seeking project in which we are engaged, and this requires that there be a self with an open future." Although it might appear a bit on the nose, I think it's important to emphasize here that Buddhist philosophy is united in its view that to conceive of one's self as an unchanging controller self plays a major part in keeping one embroiled in samsāric conditioning and thus subject to dukkha. Sāntideva puts the point in an admirably direct way: "If one does not let go of self one cannot let go of suffering, as one who does not let go of fire cannot let go of burning" (BCV VIII, 135).

But what's the reasoning here? I think Parfit gives us a really clear explanation that needs to be kept in mind when exploring the existential and soteriological dimensions of Buddhist anti-realism about the self: 
When I believed that my existence was such a further fact, I seemed imprisoned in myself. My life seemed like a glass tunnel, through which I was moving faster every year, and at the end of which there was darkness. When I changed my view, the walls of my glass tunnel disappeared. I now live in the open air. There is still a difference between my life and the lives of other people. But the difference is less. Other people are closer. I am less concerned about the rest of my own life, and more concerned about the lives of others (Parfit 1984, 281).

The glass tunnel is meant to represent a horizon that circumscribes the scope of a human life understood as a bounded self with a singular destination (death). The singular inevitability of the destination circumscribes the dimensions of the tunnel and the sense that this is all happening to me. But when we let go of the idea that there is some irreducible difference between ourselves and others - instead embracing the idea that these differences are only one of degrees - then the walls of the glass tunnel dissolve, and we can live in the open air and serve others. At the risk of simply reporting my own existential intuitions, I find this kind of aspiration to be both affirming and worthy of pursuit. Whatever meaning and happiness might result from its implementation might be very different from those varieties that Struhl and Siderits are concerned about, but it strikes me that these more selfless varieties of meaning and happiness are worth wanting and that they line up precisely with Buddhist soteriological prescriptions. So, my question at this juncture is why not just go all the way in on the Buddhist program? Struhl and Siderits seem to want the metaphysics of anti-realism but are reticent to adopt the moral psychology and soteriology that accompany the Buddhist program.

I now want to consider Struhl's take on how anti-realism about the self can be realized on the phenomenological level. It is not enough to have true beliefs about what there is. If one is serious about living a life in accordance with such beliefs, according to Buddhist soteriology, a rigorous course of action is likewise required, one that uproots and eliminates the distorting influences of those unwholesome mental states that keep us miserable and bounded to the illusion of self. Struhl puts this point in very strong terms when he claims that: "Extinguishing the illusion of self would require dispelling not just the attachment to the idea of self at the cognitive level but also the more primal appearance of self at the phenomenal level. Among other things, it would need to eliminate the first person perspective. There would be no first person perspective, because there would be no self inhabiting the person" (Struhl 2020, 129). However, I think this is too extreme. It doesn't follow that one would have to eliminate the first-person perspective without a precise definition of what that means. Here I question Struhl's reliance on Wright (2018) as a tag point for understanding Buddhist enlightenment and the difference between first and third-person perspectives.

Primary Buddhist literature is chock full of analyses of enlightenment, many of them very different. It is arguable that many canonical description of Buddhist enlightenment are incompatible with eliminitivism about the first-person perspective for the simple reason that the first-person perspective is, among other things, about a capacity to experience things as seeming a certain way from a contingent embodied 
point of view (Nagel 1974). Without such a perspective, it is unclear how the achievement of liberation - which includes insight into one's past karmic conditioning and reflexive recognition of one's own emancipation - could be possible. So, I'd be interested to hear more about how the elimination of the first-person perspective does or does not line up with more classical approaches to enlightenment contained in the Pâli suttas and elsewhere. One possible way forward here is to understand the conceptual connections between a more robust, and perhaps linguistic understanding of the first-person perspective and the kind of perspective afforded to an organism on the basis of its evolved capacities for perception and action (Baker 2013). Struhl makes passing reference to this contrast between a first-person perspective and a perceptual perspective (cf. footnote 18, bottom of p. 129) but it needs to be explained in more detail in order for Struhl's brand of elminativism about the first-person perspective to make conceptual sense in light of the Buddhist soteriological motivations that seem to undergird it.

I turn now to Struhl's construal of the epistemic role of vipassanā meditation in bringing about the phenomenological changes necessary for full appreciation of the self being an illusion. Struhl endorses a hermeneutical strategy that I will call 'verificationism', a highly empirical gloss on the role of meditation in Buddhist soteriology. Here's Struhl:

The main assumptions on which these arguments are based - the impermanence claim, the claim that the psychophysical processes are not under our control, the exhaustiveness claim, and the claim of dependent origination - all require some verification in experience, and vipassana provides a controlled way to verify the claims experientially. Through

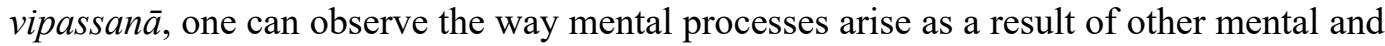
bodily processes (verifying dependent origination), one can observe how rapidly these processes arise and disappear and are replaced by other mental process (verifying impermanence), and one can ultimately come to recognize that there is nothing behind these processes that can be called a self (Struhl 2020, 130).

I wonder if there is a better way to understand the functional role of vipassana in Buddhist soteriology. Consider two of the various body contemplations in the Satipațthāna Sutta (MN I 55; Anālayo 2003). Here we are encouraged to imagine the various stages of the slow decay of a corpse, we are also asked to consider the body as merely a pile of unrelated elements. One particularly poignant example is when the body is compared to the dismembered portions of a cow being surveyed by a butcher. Even the most superficial reflection on the body shows that it is a highly integrated and self-regulating system. These contemplations do not verify a fact but project onto the body an image that is used to create an attitude in the mind of the individual whose body it is. As Shulman points out, "The example of the butcher hints that the practitioner is doing much more than neutrally scrutinizing his body... Rather, he is internalizing a philosophical position with a specific idea of what corporeal existence is about" $(2014,120)$. Additionally, this philosophical position is highly norm-laden and goal oriented; it is designed to engender a specific attitude of detachment and dispassion towards the body with an aim to liberation from dukkha. Thus, I think bald 
verificationism is not an apt epistemic model for understanding the functional role of vipassana in Buddhist soteriology, it flattens the normative import of the practice in a way that can't be sustained upon deeper reflection on the contours of those actual practices being prescribed in the primary texts. ${ }^{14}$

In conclusion, I think that Struhl's wish to combine Buddhist and modern scientific approaches to anti-realism about the self would be much enriched by further consideration of Buddhist philosophical resources outside of the Pāli suttas, especially the Abhidharmic debate between Vasubandhu and the Pudgalavādins. To be sure, I am very much an enthusiast for the Pāli literature (see Smith 2019; 2020a; 2020b) and was gratified to see how centrally they figured in Struhl's arguments. Even so, I hope my pointing to some other sources will be seen demonstrating my sympathy with Struhl's project rather than in tension with it. Second, I remain curious about the relevant similarities and differences between neuroscientific approaches to anti-realism about the self and Buddhist approaches. I have attempted to raise some questions about this to stimulate further discussion about what exactly we take ourselves to be up to when we say the self is an illusion. Finally, I have attempted to offer some alternative readings of Buddhist approaches to suffering and its cessation. I wish to again extend my thanks to Karsten Struhl for the stimulating paper and to the editors of Comparative Philosophy for inviting me to contribute to the discussion. I hope my questions are helpful to Struhl and very much look forward to reading his reply.

\section{REFERENCES}

\section{Primary Literature}

AN: Añguttara Nikāya, Bodhi, Bhikkhu (trans.) (2012) The Numerical Discourses of the Buddha: A Translation of the Anguttara Nikāya, (Somerville: Wisdom Publications).

BCV: Śäntideva's Bodhicaryāvatāra. Crosby, K. and Skilton, A., (eds and trans.) (1995) (New York: Oxford University Press).

Dhp: Dhammapada, Norman, K.R. (trans.) (1997), The Word of the Doctrine: A Translation of the Dhammapada (Oxford: PTS Society).

DN: Digha Nikāya, Walshe, M. (trans.) (1995), The Long Discourses of the Buddha: A Translation of the Digha Nikāya (Somerville: Wisdom Publications).

MN: Majjhima Nikāya, Bodhi, Bhikkhu (trans.) (2005), The Middle Length Discourses of the Buddha: A Translation of the Majjhima Nikāya (Somerville: Wisdom Publications).

SN: Samyutta Nikāya Bodhi, Bhikkhu (trans.) (2000), The Connected Discourses of the Buddha: A Translation of the Samyutta Nikāya (Somerville: Wisdom Publications).

\footnotetext{
${ }^{14}$ Interestingly, Struhl $(2020,131)$ approvingly cites Shulman $(2014,164)$ but seems to miss Shulman's deeper point about the function of mindfulness.
} 
Vis: Buddhaghosa's Visuddhimagga, Bhikkhu Ñāṇamoli (trans) (2000), Visuddhimagga: The Path of Purification (Seattle: BPS Pariyatti).

Secondary Literature

Anālayo (2003), Satipațthāna: The Direct Path to Realization (Birmingham: Windhorse).

Baker, L.R. (2013), Naturalism and the First-Person Perspective (New York: Oxford University Pres).

Batchelor, S. (2011), Confessions of a Buddhist Atheist (New York: Spiegel and Grau). Bodhi, Bhikkhu (2017) "Anattā as Strategy and Ontology" in Investigating the Dhamma: A Collection of Papers (Kandy, Sri Lanka: Buddhist Publication Society).

Christoff, K., Cosmelli, D., Legrand, D., and Thompson, E. (2011), "Specifying the Self for Cognitive Neuroscience" in Trends in Cognitive Science 15.3: 104-12. $<$ https://doi.org/10.1016/j.tics.2011.01.001>

Davis, J.H. (2016), "The Scope for Wisdom": Early Buddhism on Reasons and Persons", in The Bloomsbury Research Handbook of Indian Ethics, ed. Shyam Ranganathan (London: Bloomsbury Academic).

Duerlinger, J. (2009), "Vasubandhu's Abhidharmakośa: The Critique of the Pudgalavādins' Theory of Persons" in Edelglass, W. and Garfield, J. (eds)., Buddhist Philosophy: Essential Readings (NewYork: Oxford University Press).

Garfield, J. (2015), Engaging Buddhism: Why it Matters to Philosophy (New York: Oxford University Press).

Gombrich, R. (2009), What the Buddha Thought (Bristol: Equinox).

Hamilton, S. (2000), Early Buddhism: A New Approach - The 'I' of the Beholder (New York: Routledge).

Lusthaus, D. (2009), "Pudgalavāda Doctrines of the Person", in Edelglass, W. and Garfield, J. (eds), Buddhist Philosophy: Essential Readings (New York: Oxford University Press).

Metzinger, T. (2003), Being No One (Cambridge: MIT Press).

Metzinger, T. (2009), The Ego Tunnel: The Science of the Mind and the Myth of the Self (New York: Basic Books).

Metzinger, T. (2011), "The No-Self Alternative”, in Shaun Gallagher (ed.), The Oxford Handbook of the Self (New York: Oxford University Press).

Nagel, T. (1974), "What is it like to be a bat?", The Philosophical Review 83.4: 43550. $<$ https://doi.org/10.2307/2183914>

Olendzki, A. (2016), Untangling Self: A Buddhist Investigation of Who We Really Are (Somerville, Massachusetts: Wisdom Publications).

Parfit, D. (1984), Reasons and Persons (New York: Oxford University Press).

Shulman, E. (2014), Rethinking the Buddha: Early Buddhist Philosophy as Meditative Perception (New York: Cambridge University Press).

Siderits, M. (2013), "Buddhas as Zombies: A Buddhist Reduction of Subjectivity", in Siderits, M., Thompson, E., and Zahavi, D. (eds) Self, No Self? Perspectives from 
Analytical, Phenomenological, and Indian Traditions (New York: Oxford University Press).

Siderits, M. (2015), Personal Identity and Buddhist Philosophy: Empty Persons (2 ${ }^{\text {nd }}$ Edition) (Burlington, Vermont: Ashgate Publishing Company).

Smith, S.M. (2019), "A Buddhist Analysis of Affective Bias" in Journal of Indian Philosophy 47.1: 15-85. <https://doi.org/10.1007/s10781-019-09379-0>

Smith, S. M. (2020a), "Paying Attention to Buddhaghosa and Pāli Buddhist Philosophy", Philosophy East and West 69.4: 1125-5, review of Ganeri (2017). $<10.1353 /$ pew.2019.0089>

Smith, S. M. (2020b), "A Pāli Buddhist Philosophy of Sentience: Reflections on Bhavanga Citta", Sophia 59: 457-88.

Smith, S. M. (forthcoming), "The Negation of Self in Indian Buddhist Philosophy", Philosopher's Imprint.

Struhl, K. (2020), "What Kind of Illusion is the Illusion of Self?", Comparative Philosophy 11.2: 113-139. <https://doi.org/10.31979/2151-6014(2020).110208>

Thompson, E. (2015), Waking, Dreaming, Being: Self and Consciousness in Neuroscience, Meditation, and Philosophy (New York: Columbia University Press).

Thompson, E. (2020), Why I am Not a Buddhist (New York: Columbia University Press).

Walsh, D. (2015), Organisms, Agency, and Evolution (Cambridge: Cambridge University Press).

Westerhoff, J. (2009), Nāgārjuna's Madhyamaka (New York: Oxford University Press).

Wright, R. (2018), Why Buddhism is True: The Science and Philosophy of Meditation and Enlightenment (New York: Simon and Schuster).

Wynne, A. (2009), "Miraculous Transformation and Personal Identity: A Note on the First anātman Teaching of the second Sermon", Thai International Journal of Buddhist Studies 1: 85-113. 